\title{
On the Development of an Al4.8 wt\% Cu Alloy Obtained from Recycled Aluminum Cans Designed for Thixoforming Process
}

\author{
Ronan Miller Vieira, Gianni Ferreira Alves Moreira, \\ André Itman Filho, and Estéfano Aparecido Vieira
}

\begin{abstract}
Instituto Federal do Espírito Santo (IFES), Campus Vitória, Avenida Vitória 1729, Jucutuquara, 29040-780 Vitória, ES, Brazil
\end{abstract}

Correspondence should be addressed to Estéfano Aparecido Vieira; estefanovieira@ifes.edu.br

Received 8 May 2016; Revised 17 July 2016; Accepted 20 July 2016

Academic Editor: Pavel Lejcek

Copyright (C) 2016 Ronan Miller Vieira et al. This is an open access article distributed under the Creative Commons Attribution License, which permits unrestricted use, distribution, and reproduction in any medium, provided the original work is properly cited.

\begin{abstract}
This work has focused on the development of a new aluminum alloy containing 4.8 wt $\%$ of $\mathrm{Cu}$ alloy obtained from recycled aluminium cans designed for thixoforming process. After the step of melting and solidification of the alloy in a metallic permanent mold, samples were solution heat treated at $525^{\circ} \mathrm{C}$ for times ranging from $2 \mathrm{~h}$ to $48 \mathrm{~h}$, quenched in water and followed by natural aging. Results have shown the evolution of hardness so from them solubilization solution heat treatment was chosen for $24 \mathrm{~h}$. The best condition for aging was $190^{\circ} \mathrm{C}$ during $3 \mathrm{~h}$. With this data pieces were thixoforged at $580^{\circ} \mathrm{C}$ and $615^{\circ} \mathrm{C}$ corresponding, respectively, to solid fraction $\left(f_{s}\right)$ of 0.8 and 0.6 . The optimized T6 temper was applied and tensile tests were performed. The mechanical properties obtained are compatible with those obtained for consolidated alloys processed in semisolid state (SS) and after T6 temper hardness increases from $95 \mathrm{HB}$ to $122 \mathrm{HB}$ and the best results were a tensile strength of $324 \mathrm{MPa} \pm 10 \mathrm{MPa}$, yield strength of $257 \mathrm{MPa} \pm 18 \mathrm{MPa}$, and an elongation of $7.1 \% \pm 1 \%$. For alloys designed for thixoforming process, these results are in accordance with what was expected whereas globular microstructure, high ductility, and good performance under cyclic conditions are desirable.
\end{abstract}

\section{Introduction}

The automotive industries are seeking for new technologies to reduce fuel consumption in vehicles; therefore, the demand for lighter and stronger materials is increasing. Aluminum alloys are an alternative to replace many mechanical components because they bring weight reduction associated with good resistance. The search for chemical compositions and processes that ensure adequate mechanical properties is the explanation for several studies done in recent decades [18]. Among these alternatives, the thixoforging process for aluminum alloys is a good choice since pieces produced by this way can be subjected to T6 temper. Some works had demonstrated the better mechanical properties of thixoforged products than those produced by cast or die casting process [9-13]. The T6 temper aims to promote the formation of thin precipitates dispersed and maximizing the mechanical strength of the alloy. The production of alloys such as A356 and 2024 have their origin from raw materials with a high purity, therefore having a high cost. This is a problem since those alloys can not be obtained from recycled alloys with high content of harmful elements such as Fe. Usually the $\mathrm{Fe}$ is an undesired element in aluminum alloys and by economically feasible way it cannot be removed leaving only the dilution as an option when you want to reduce its concentration. The aluminum alloy cans are made of 3004 and 5182 alloys that come from the lid and body of can, respectively, and some residual elements are present too. The recycle process is economically viable; however the mix obtained cannot be applied directly to produce useful products and additions are always necessary as, for example, commercial pure aluminum (99.7\%) or alloy elements. 


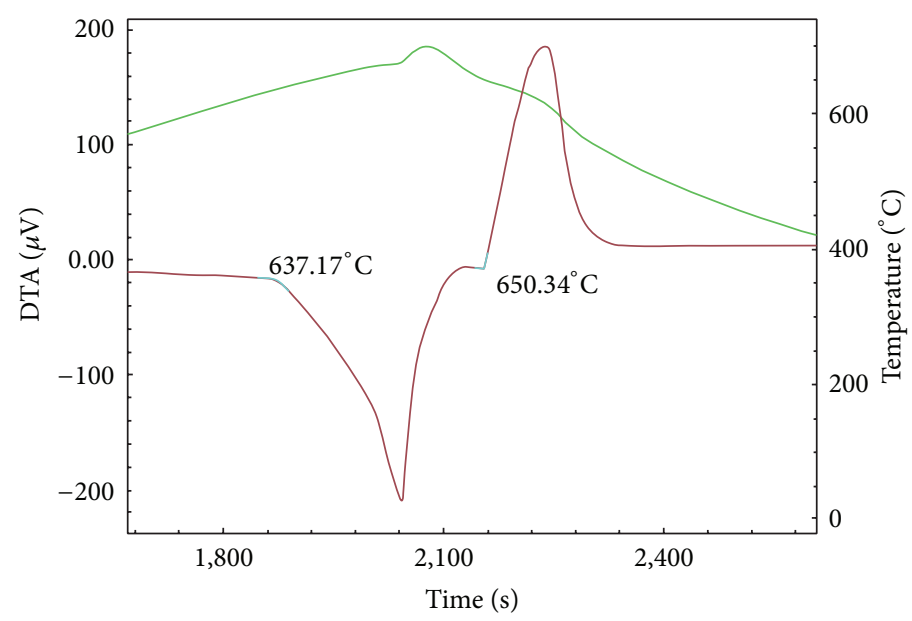

(a)

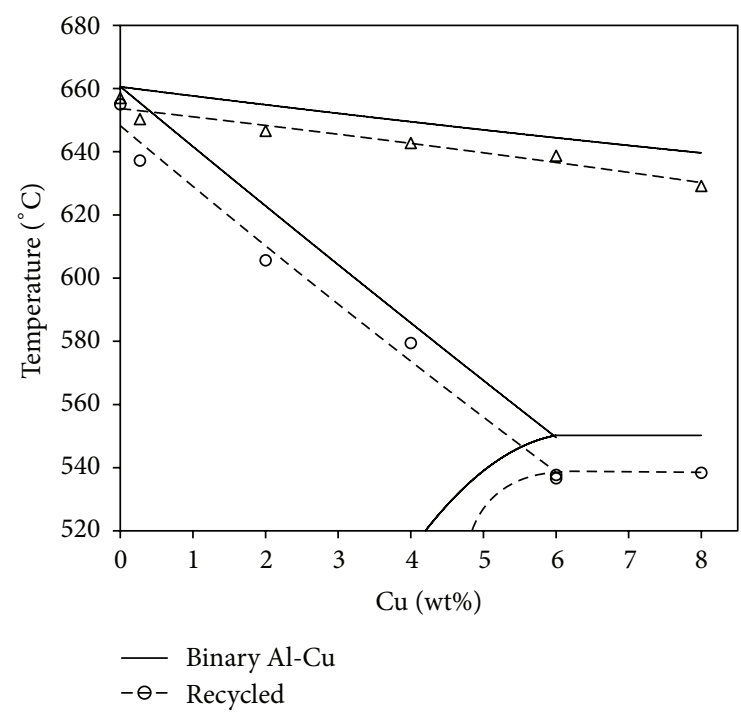

(b)

FIGURE 1: DTA results. (a) Example of the result obtained for the alloy with $0.23 \mathrm{wt} \%$ of $\mathrm{Cu}$ and (b) pseudobinary phase diagram of Al alloy recycled with $\mathrm{Cu}$ addition.

TABLE 1: Chemical composition of Al4.8 wt\% Cu produced from aluminium cans scrap.

\begin{tabular}{lccccccccrrr}
\hline Alloy & $\mathrm{Si}$ & $\mathrm{Fe}$ & $\mathrm{Cu}$ & $\mathrm{Mn}$ & $\mathrm{Mg}$ & $\mathrm{Cr}$ & $\mathrm{Zn}$ & $\mathrm{Ti}$ & $\mathrm{Residual}$ & $\mathrm{Al}$ \\
\hline Al4.8 wt\% $\mathrm{Cu}$ & 0.22 & 0.57 & 4.8 & 0.78 & 1.32 & 0.015 & 0.036 & 0.045 & 0.15 & Balance \\
\hline
\end{tabular}

The aim of this work was to establish parameters to determine the time and temperature to optimize the mechanical properties of a new recycled aluminum alloy containing $4.8 \mathrm{wt} \% \mathrm{Cu}$.

\section{Experimental}

The first step of this work was to produce a recycled alloy from beverage aluminum cans and the detailed steps were the same as described in a recent work developed by Reis et al. [4]. The recycled alloy was poured into a permanent mold and ingots with around $0.4 \mathrm{~kg}$ were produced. The chemical analysis was performed on optical emission spectrometer WAS-Oxford Model Foundry Master Pro and in wt $\%$ as follows: $\mathrm{Si}=0.28 ; \mathrm{Fe}$ $=0.61 ; \mathrm{Cu}=0.23 ; \mathrm{Mn}=1.03 ; \mathrm{Mg}=1.91 ; \mathrm{Cr}=0.03 ; \mathrm{Zn}=0.25$; $\mathrm{Ti}=0.03$; residual $=0.15$ with maximum of 0.05 for each and Al balance.

In order to produce an alloy adequate to the semisolid process a gap in semisolid state (SS) is needful sufficiently large to turn the control of the solid fraction $\left(f_{s}\right)$ doable and the usual gap must be at least $40^{\circ} \mathrm{C}$. Therefore, the prime alloy is not in condition to be used in SS process and to start it was used to produce several samples with $\mathrm{Cu}$ content ranging from $0 \mathrm{wt} \%$ to $8 \mathrm{wt} \%$. Each alloy produced was analyzed using a Differential Thermal Analysis (DTA) module by Shimadzu DTA-50. For example, for the first alloy with only $0.23 \%$ of $\mathrm{Cu}$ the beginning of the fusion starts at approximately $637^{\circ} \mathrm{C}$ and ends at $650^{\circ} \mathrm{C}$ as shown in Figure $1(\mathrm{a})$. This is an example of short gap that is not adequate to the semisolid process. Throughout the use of other compositions, it was possible to create a pseudobinary diagram as function of the $\mathrm{Cu}$ content as shown in Figure 1(b) indicated by doted lines since the continuous lines indicate the binary diagram for the Al-Cu. Therefore, these data allowed establishing the composition range where the gap of temperature is at least $40^{\circ} \mathrm{C}$ with coexistence of liquid and solid. What is more is a better control of the solid fraction as function of temperature. From Figure 1(b) the content of $4.8 \mathrm{wt} \%$ of $\mathrm{Cu}$ was a typical composition that would allow an expressive semisolid (SS) field and it was chosen.

In the second step of this work, the prime ingots were melted again at $690^{\circ} \mathrm{C}$ and the alloy was submitted to a degassing process using a mix containing 97\% of Ar and 3\% of $\mathrm{Cl}_{2}$ during $5 \mathrm{~min}$. This procedure aimed to remove oxides present in the alloy and also the dissolved hydrogen. After this procedure the dross was removed and finally metallic $\mathrm{Cu}$ was added aiming at a content of $4.8 \mathrm{wt} \%$. Moreover, $0.5 \mathrm{wt} \%$ of $\mathrm{TiBAl}$ (Al5\% Til\%B) was added to promote the refining of grains. The alloy obtained was poured into a permanent mold with dimensions of $4.5 \times 15 \times 20 \mathrm{~cm}$. Table 1 shows the final chemical composition of the new alloy with $4.8 \mathrm{wt} \%$ of $\mathrm{Cu}$.

2.1. Establishing Best Conditions for T6 Temper. Throughout the investigation the minimum time for maximum solubilization of the all precipitates was defined. Using the data obtained in Figure $1(\mathrm{~b})$ the $525^{\circ} \mathrm{C}$ for this step was chosen. Therefore, to determine the time for optimizing solution heat treatment, samples were heated at $525^{\circ} \mathrm{C}$. 


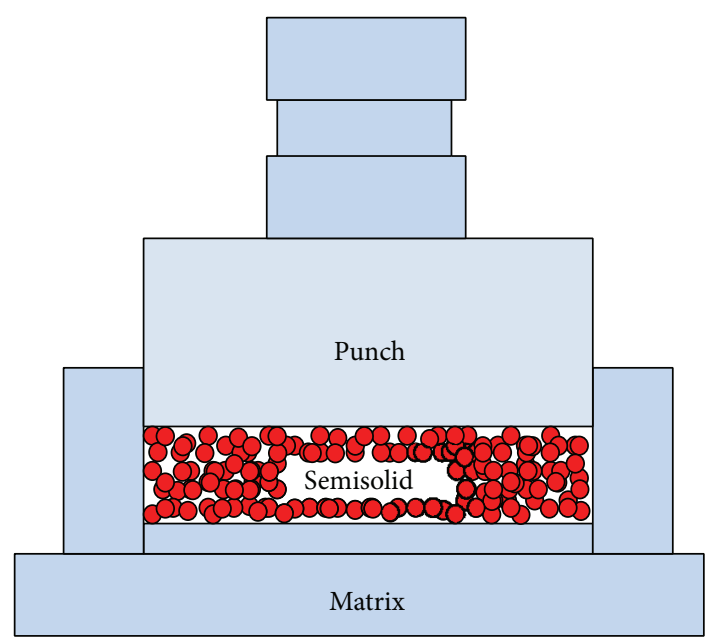

(a)

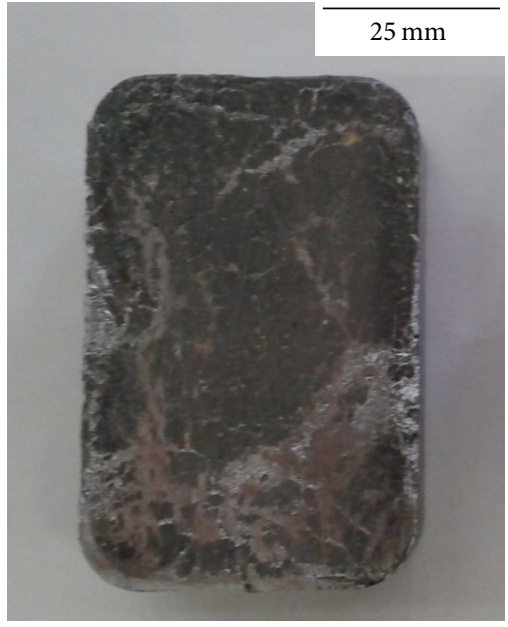

(b)

FIgURE 2: Schematic representation of the matrix used for the thixoforging process. (a) Assembly of the matrix. (b) Thixoforged sample.

The samples were solubilized during 2, 6, 24, and $48 \mathrm{~h}$ and quenched in water and after that they were naturally aged. The efficiency of the heat treatment was evaluated by Vickers Hardness measurements. After this step the best time and temperature were investigated for the artificial aging (T6). The maximum temperature to be studied was determined by a complementary study using a differential scanning calorimetric (DSC) brand Netzsch Jupiter ${ }^{\circledR}$ DSC 404 F3 with argon atmosphere a heating rate fixed at $10^{\circ} \mathrm{C} / \mathrm{min}$ until $500^{\circ} \mathrm{C}$ and signs related to precipitation as function of time and temperature were collected throughout the variation of energy during the heating. The resulting peaks represent the energy involved in the precipitation process and the onset of the them has indicated the higher temperature that alloy would be submitted in the precipitation heat treatment.

2.2. Thixoforging Process. From the plate produced in second step, thixoforged parts were made. Thixoforging four pieces at $580^{\circ} \mathrm{C}$ and $615^{\circ} \mathrm{C}$ was decided, respectively, corresponding to solid fractions of $f_{s}=0.8$ and 0.6 . In this case again Figure 1 has helped to choose those temperatures. The heating rate was around $20^{\circ} \mathrm{C} / \mathrm{min}$ and the chosen temperatures were sufficiently higher to afford a good condition for the forming process. Furthermore, the resting time of $20 \mathrm{~min}$ and $30 \mathrm{~min}$ was necessary to ensure the formation of the typical globular microstructure of thixoforged parts in semisolid process. A resting time too much short can restrain the conformation and on the other hand if it would be too much long an excess of hydrogen from atmosphere could be introduced causing some porosity. The best choice is a time as short as possible since the conformation and globular structure are guaranteed. Also, thixoforged parts were submitted at more T6 promising temper studied. The parts obtained have been used for preparation of specimens to perform tensile tests.
The matrix used for the thixoforging process was made by AISI H13 steel which can withstand high operating temperatures. The shape of the thixoforged parts was very simple since the main focus of this work was not studying flow conditions. The mounting of the thixoforged equipment basically consists of a conventional press, a base for stamping, the matrix, a punch, and a furnace for heating the alloy. The forming force was maintained at about $15 \mathrm{t}$ and Figure 2(a) shows a schematic of the apparatus used.

The preconditioning used to produce the characteristic globular microstructure in SS was the thermomechanical heat treatment (THT) similar to a well-known thermomechanical method, the strain-induced melt-activation (SIMA) [15]. The preconditioned raw material was used to produce the parts as follow: samples were placed in an electric furnace and when the alloy in the SS has reached the resting time desired it was removed from the furnace and placed into the matrix permitting the conformation and four pieces were obtained with dimensions of $80 \times 50 \mathrm{~mm}$ and a thickness between 20 and $30 \mathrm{~mm}$. Figure 2(b) shows a thixoforged piece. The matrix before being used was heated with a propane torch (LPG). This procedure besides improving the flow conditions has avoided possible liquid metal projections due to vaporization of humidity.

Finally, the thixoforged pieces were submitted to the T6 temper and tensile test was made from them. The results allowed evaluating the mechanical properties for the new alloy reaching correlations with its microstructure. For each experiment at least 3 tensile specimens were made. Figure 3 shows the dimensions of the machined test specimens. All mechanical tests were performed in a universal machine tensile testing brand EMIC model DL10000.

2.3. Microstructural Characterization. The microstructure of the samples was examined by optical microscopy. The preparation process went through a roughing by sanding 
TABLE 2: Results of the tensile tests.

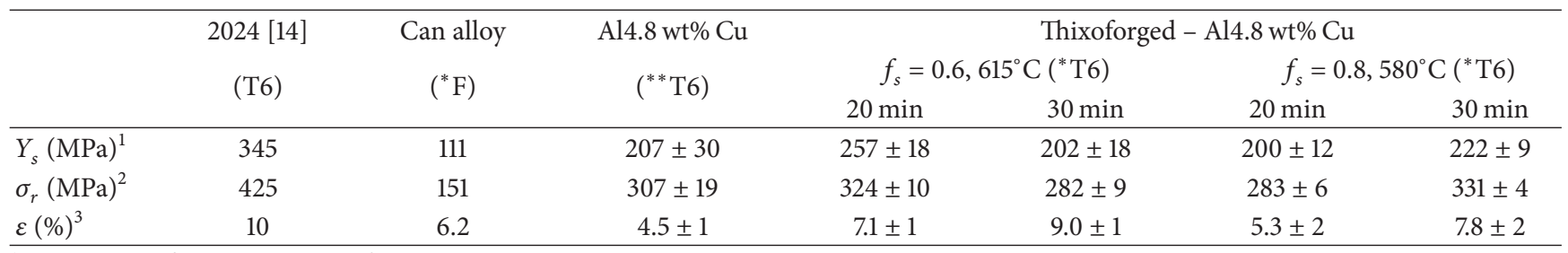

${ }^{1}$ Yield strength. ${ }^{2}$ Ultimate strength. ${ }^{3}$ Elongation. ${ }^{*} \mathrm{~F}$ (as cast). ${ }^{* *} \mathrm{~T} 6$ (solutionizing during $24 \mathrm{~h}$ at $525^{\circ} \mathrm{C}$ and aging during $3 \mathrm{~h}$ at $190^{\circ} \mathrm{C}$ ).

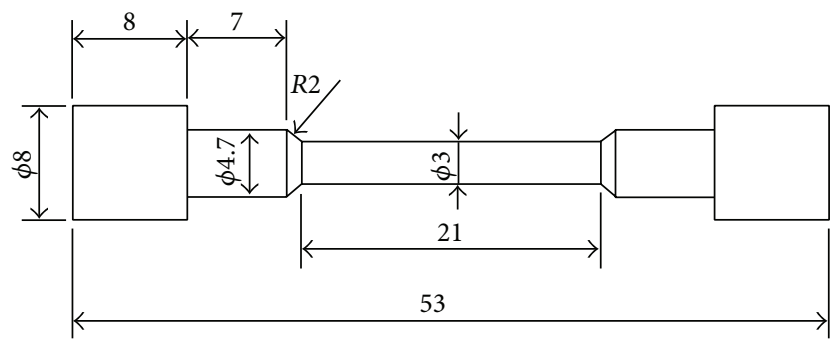

FIgURE 3: Specimen dimensions for tensile test in mm.

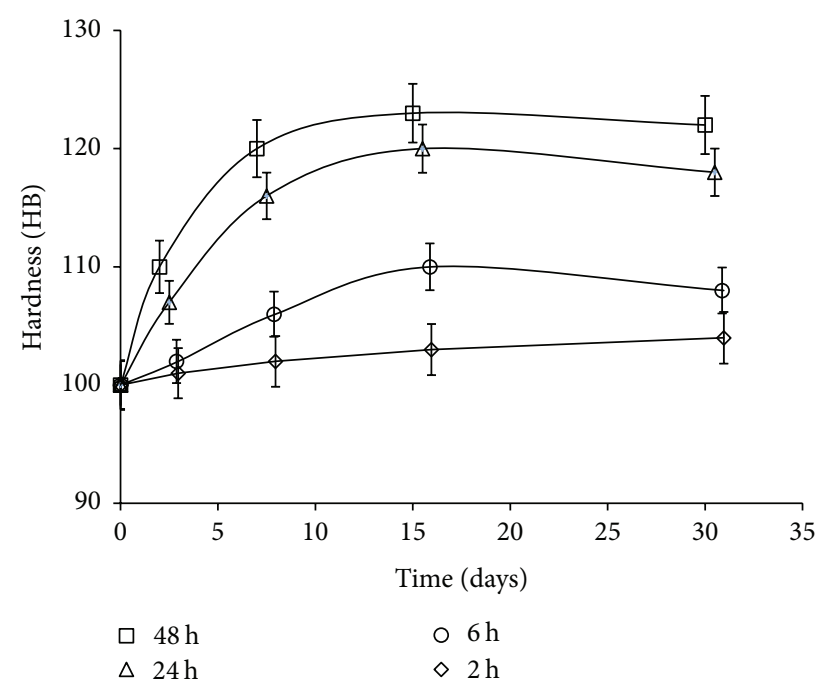

FIGURE 4: Evolution of hardness to the natural aging of the new alloy $\mathrm{Al} 4.8 \mathrm{wt} \% \mathrm{Cu}$ solution heat treatment under different times.

using water sandpaper of silicon carbide with grain sizes ranging from 320 to 1000 and were polished with chromium oxide $\mathrm{Cr}_{2} \mathrm{O}_{3}$. The finish was made with colloidal silica $0.4 \mu \mathrm{m}$. Finally an attack made was with a solution of hydrofluoric acid $0.5 \%$ HF during 5 min.

\section{Results and Discussion}

Hardness curves for the different samples submitted to the solution heat treatment during different times and naturally aged are presented in Figure 4. The best result was obtained for $48 \mathrm{~h}$ but the treatment during 24 reached almost the same result. Although the results of this study has shown that the time of $48 \mathrm{~h}$ is the best condition, however, due to the slight increase in hardness it was chosen to perform solution heat treatment during $24 \mathrm{~h}$.

In Figure 5 the micrographs are presented as cast and after the solution heat treatment at $525^{\circ} \mathrm{C}$ during $48 \mathrm{~h}$. The micrographs suggest clearly that there is reduction in the volume fraction of precipitates in the solutionized sample. The solution heat treatment also increases the grain size. As expected a lot of amount of precipitates that are mainly in the grain boundaries were dissolved in the aluminum bulk of the grains. The main purpose after this step is to perform T6 temper to form new precipitates with coherent interface that will produce an alloy with higher resistance $[16,17]$.

Usually the aging step is performed under temperatures from $130^{\circ} \mathrm{C}$ up to $280^{\circ} \mathrm{C}$. Figure 6 compares calorimetric differential results obtained for samples solutionized under different times and it is possible to identify that the temperature of approximately $240^{\circ} \mathrm{C}$ is the maximum feasible to perform artificial age. Although Figure 7 shows clearly that $2 \mathrm{~h}$ is probably sufficient to a good solubilization it was chosen $24 \mathrm{~h}$ to ensure higher hardness and strength. After the process of precipitation, the samples were heated again and the precipitation peaks disappeared completely. From this result to make studies for the artificial aging was decided at temperatures of $190^{\circ} \mathrm{C}$ and $230^{\circ} \mathrm{C}$.

From samples solutionized during $24 \mathrm{~h}$ the studies were performed under artificial aging and results are in Figure 7. The maximum hardness occurs around $3 \mathrm{~h}$ under a temperature of $190^{\circ} \mathrm{C}$ reaching a hardness of $121 \mathrm{HB}$ and at $230^{\circ} \mathrm{C}$ the hardness reached was $112 \mathrm{HB}$. Therefore, for thixoforged parts T6 temper was chosen at $190^{\circ} \mathrm{C}$ during $3 \mathrm{~h}$.

The results obtained in Figures 6 and 7 have been used to stablish the condition for the heat treatment in thixoforged parts using the new alloy Al4.8wt\% Cu. In Table 2 all results of tensile tests summarized are presented. Usually the mechanical properties of the alloys processed in SS are higher than those produced in conventional casting process. However, Table 1 compares the results obtained with a commercial alloy 2024 and the conclusion is that properties obtained for the new alloy processed in SS are limited. But the processing for 2024 alloy was the extrusion, and higher performance is expected for alloys mechanically processed. For alloys processed in the SS was expected a yield strength between 257 and $280 \mathrm{MPa}$, ultimate strength 


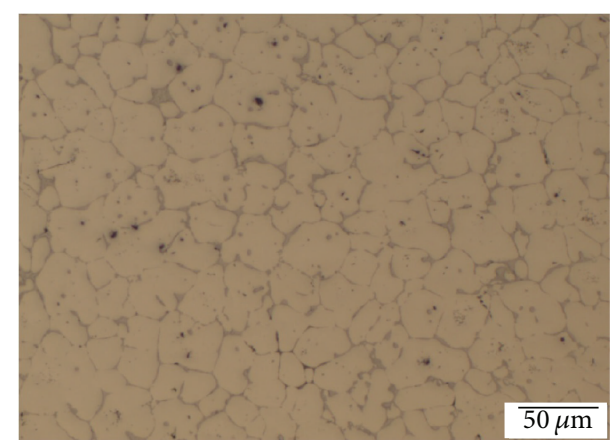

(a)

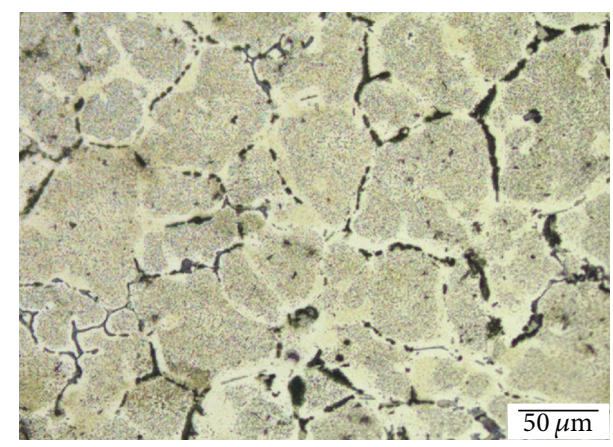

(b)

FIgURE 5: Microstructure of Al4.8 wt\% Cu. (a) As cast. (b) after soaking for $24 \mathrm{~h}$ at $525^{\circ} \mathrm{C}$. Samples were etched with $0.5 \% \mathrm{HCl}$ solution during $5 \mathrm{~min}$.

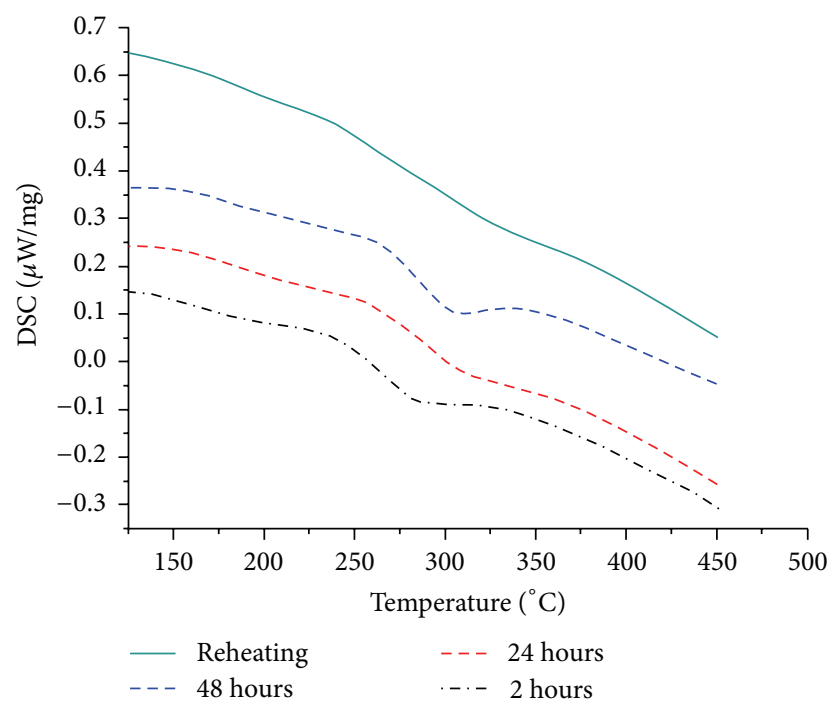

FIGURE 6: Differential scanning calorimetry of solutionized samples Al4.8 wt\% Cu. Peaks show precipitation in the recycled aluminum alloy.

of $318-344 \mathrm{MPa}$, and a minimum of elongation of $6 \%$ [13]. Some samples reached those limits and others do not; however in all examples was obtained higher performance for thixoforged parts when likened with the same alloy nonprocessed in SS. An important aspect that must be pointed is the improvement of the elongation which can indicate a likely better behavior of the part when it is applied under cyclic conditions; this is a very important aspect for automotive industry. The ultimate tensile strength decreases with the resting time for lower solid fraction $\left(f_{s}=0.6\right)$ and the opposite occurs for higher solid fraction $\left(f_{s}=0.8\right)$ and the same behavior for the yield strength was obtained. The results have shown that prolonged resting time associated with lower solid fraction results in higher elongation.

In Figure 8 are presented some examples of tensile tests curves. The increase of the resistance of the alloy may be associated mainly due to the formation of the precipitates such as $\mathrm{Al}_{2} \mathrm{Cu}$ and in 2011 a very interesting study was

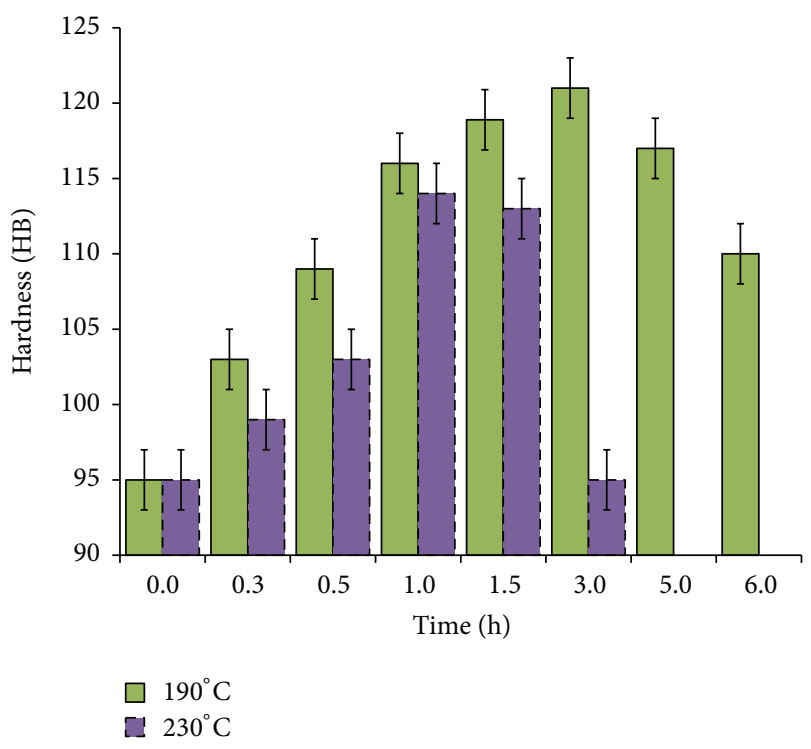

Figure 7: Curves for T6 temper for new alloy recycled $\mathrm{Al} 4.8 \mathrm{wt} \% \mathrm{Cu}$.

published showing the precipitation mechanism of an alloy with chemical composition similar to this study by Birol [14] and it was demonstrated that under the artificial aging there is a significant gain in hardness.

In Figure 9 are presented the microstructures obtained for the parts thixoforged. In both solid fractions it is possible to confirm sine increase of the globular grain as function of the time. The microstructural evolution probably followed the well-known Ostwald Ripening model adapted for systems in SS [18]. For all samples were observed particles with globular morphology which has considerable importance for ensuring higher fatigue resistance. Some dark regions appear to be high porosity but actually those are due to the etching of the samples with $\mathrm{HCl}$ for prolonged times to reveal the globular microstructure and Figure $9(\mathrm{e})$ is a typical example of a nonetched sample that exemplifies the low level of porosity of the samples. 


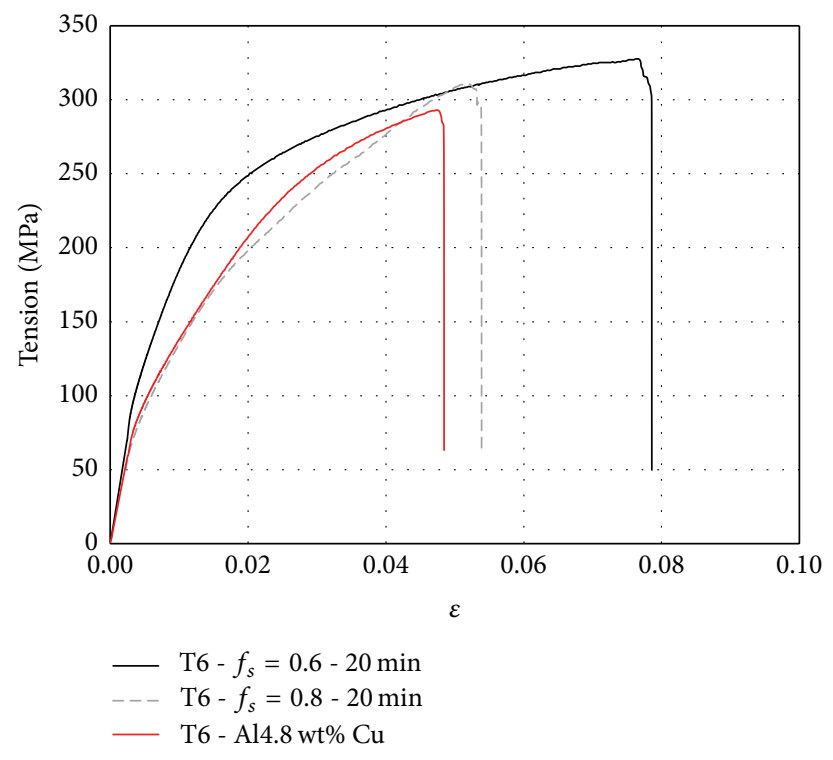

FIGURE 8: Some typical tensile curves obtained from different thixoforged samples submitted to the T6 heat treatment (solutionizing during $24 \mathrm{~h}$ at $525^{\circ} \mathrm{C}$ and aging during $3 \mathrm{~h}$ at $190^{\circ} \mathrm{C}$ ).

It is very difficult to correlate the mechanical properties with the final result of the microstructure, since the alloy is maintained longer in the SS, as consequence particles grow; besides hydrogen is absorbed by liquid phase and some precipitates are dissolved in the liquid. The growth of particles probably promotes lower resistance as the example presented by Zoqui et al. in 1998 [19]. The presence of hydrogen could lead to reduction of the strength due to formation of bubbles in a subsequent heat treatment such as solutionizing followed by T6 temper. Finally, the dissolution of precipitates can promote better properties due to the reduction of coarse type. Moreover, unknown factors may also operate and therefore to establish rules that allows us to know clearly how each of these factors are contributing to improve or spoil the final mechanical properties is a challenge. In summary, it was highlighted that the thixoforged process of the new alloy has shown a good way to obtain adequate properties and the typical globular microstructure used in SS process. The use of recycled cans can be a promising way for large scale production of mechanical components that can be applied in the automotive industry. Some complementary studies related with fatigue are necessary to finally prove the feasibility of the use of this alloy commercially for production of parts.

\section{Conclusion}

In this work an innovative way to recycle aluminium can scraps has been proposed and it has demonstrated the feasibility of its use with copper addition to produce a raw material to be used in thixoforming process producing parts with properties required by the automotive industry. Therefore, thixoforming process of this new alloy at temperatures between $580^{\circ} \mathrm{C}$ and $615^{\circ} \mathrm{C}$ and for resting time in SS from $20 \mathrm{~min}$ to $30 \mathrm{~min}$ is feasible.
The solution heat treatment which gives higher hardness for the recycled $\mathrm{Al} 4.8 \mathrm{wt} \% \mathrm{Cu}$ alloy was that one performed during $48 \mathrm{~h}$ at $525^{\circ} \mathrm{C}$. However, results have shown that $24 \mathrm{~h}$ of treatment is also adequate to promote some solutionizing. In the differential scanning calorimetric analysis, it was stablishing that total precipitation occurs for temperatures higher than around $240^{\circ} \mathrm{C}$. Therefore, the previous studies have shown that the best treatment to maximize the strength of the new alloy should be a T6 temper during $3 \mathrm{~h}$ at $190^{\circ} \mathrm{C}$.

The mechanical properties obtained for the thixoforged parts using the raw material $\mathrm{Al} 4.8 \mathrm{wt} \% \mathrm{Cu}$ are in accordance with that one expected for pieces produced using conventional raw materials for semisolid processing. A yield strength, ultimate strength, and elongation up to, respectively, $257 \mathrm{MPa}, 331 \mathrm{MPa}$, and 9\% were reached. These values are consistent with other references.

Parts thixoforming have resulted in an integrate material with typical globular microstructure designed for SS process. This result indicates that the recycled alloy may have a high performance when submitted to the fatigue applications. Some complementary studies are necessary.

The mechanical properties of $\mathrm{Al} 4.8 \mathrm{wt} \% \mathrm{Cu}$ is very sensitive to the resting time and temperature. The results suggest that under a fixed temperature there is a resting time that maximize mechanical properties. For example, for higher solid fraction higher resting time is necessary to obtain better results.

\section{Competing Interests}

The authors declare that there are no competing interests regarding the publication of this paper. 


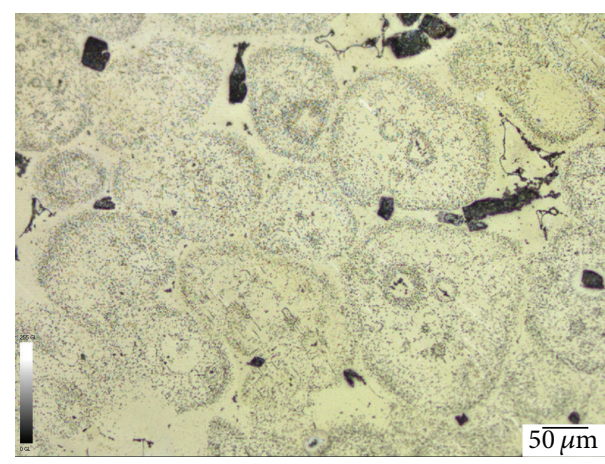

(a)

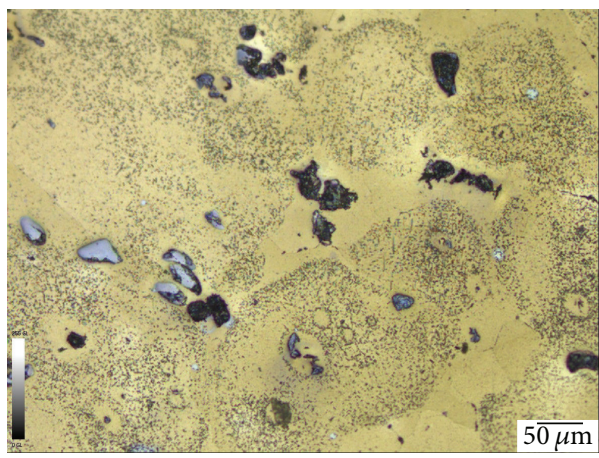

(c)

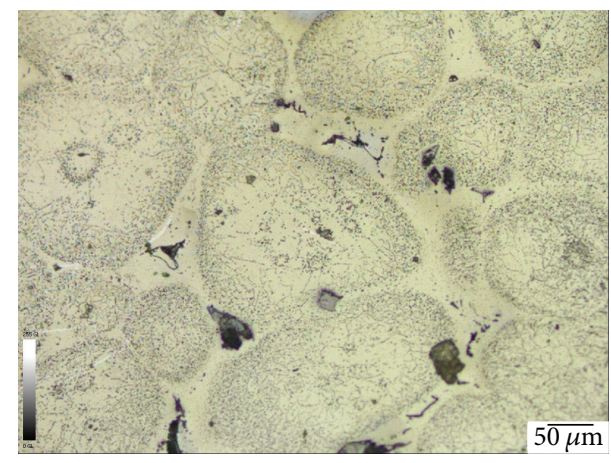

(b)

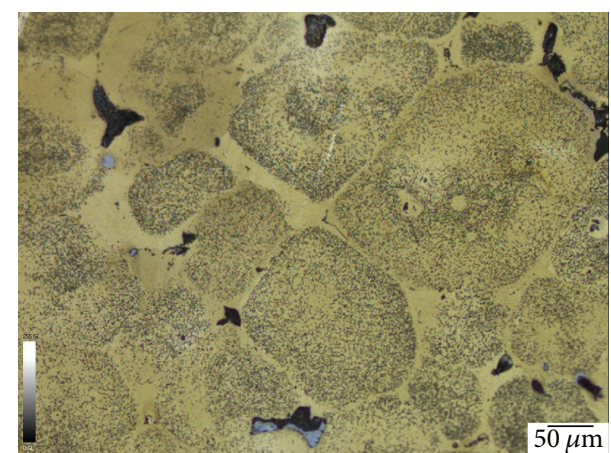

(d)

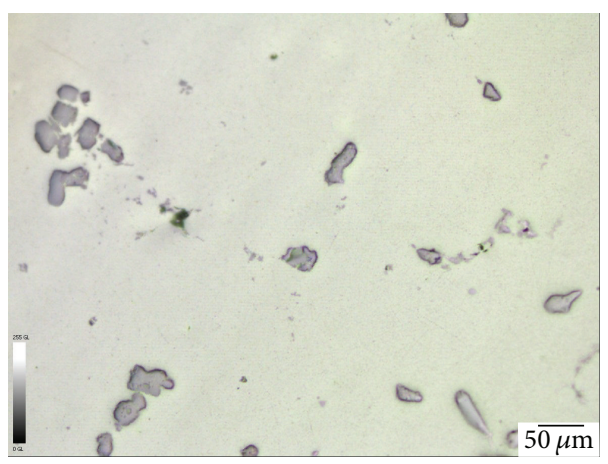

(e)

FIGURE 9: Microstructure of samples thixoforged of the Al4.8 wt\% Cu alloy (a) $f_{s}=0.6$ and resting time 20 min, (b) $f_{s}=0.6$ and resting time $30 \mathrm{~min}$, (c) $f_{s}=0.8$ and resting time $20 \mathrm{~min}$, (d) $f_{s}=0.8$ and resting time $30 \mathrm{~min}$, and (e) $f_{s}=0.6$ and resting time 20 min without etching.

\section{Acknowledgments}

The authors are gratefully acknowledging the CAPES, FINEP, CNPq, and FAPES (Brazilian Research Funding Agencies) for financial support.

\section{References}

[1] D. G. Eskin, Suyitno, and L. Katgerman, "Mechanical properties in the semi-solid state and hot tearing of aluminium alloys," Progress in Materials Science, vol. 49, no. 5, pp. 629-711, 2004.

[2] Y. J. Li, S. Brusethaug, and A. Olsen, "Influence of $\mathrm{Cu}$ on the mechanical properties and precipitation behavior of $\mathrm{AlSi}_{7} \mathrm{Mg}_{0.5}$ alloy during aging treatment," Scripta Materialia, vol. 54, no. 1 , pp. 99-103, 2006.
[3] W. S. Miller, L. Zhuang, J. Bottema et al., "Recent development in aluminium alloys for the automotive industry," Materials Science and Engineering: A, vol. 280, no. 1, pp. 37-49, 2000.

[4] A. A. Reis, J. R. De Oliveira, R. M. De Oliveira, and E. A. Vieira, "Thixoforging of Al-3.8\% Si alloy recycled from aluminum cans," Materials Science and Engineering: A, vol. 607, pp. 219$225,2014$.

[5] E. Sjölander and S. Seifeddine, "The heat treatment of Al-Si-CuMg casting alloys," Journal of Materials Processing Technology, vol. 210, no. 10, pp. 1249-1259, 2010.

[6] J. L. Tao, W. G. Hui, Y. W. Shu, Z. Y. Gang, and L. S. Shan, "Effect of heat treatment on microstructure and dimensional stability of ZL114A aluminum alloys," Transactions of Nonferrous Metals Society of China, vol. 20, no. 11, pp. 2124-2128, 2010. 
[7] G. Wang, Q. Sun, L. Feng, L. Hui, and C. Jing, "Influence of Cu content on ageing behavior of AlSiMgCu cast alloys," Materials \& Design, vol. 28, no. 3, pp. 1001-1005, 2007.

[8] E. J. Zoqui and M. H. Robert, "Structural modifications in rheocast $\mathrm{Al}-\mathrm{Cu}$ alloys by heat treatment and implications on mechanical properties," Journal of Materials Processing Technology, vol. 78, no. 1-3, pp. 198-203, 1998.

[9] D. H. Kirkwood, "Semisolid metal processing," International Materials Review, vol. 39, no. 5, pp. 173-189, 1994.

[10] G. Chiarmetta, "Thixoforming of automobile components," in Proceedings of the 4th International Conference on Semi-Solid Processing of Alloys and Composites, pp. 204-207, Sheffield, UK, 1996.

[11] H. V. Atkinson, P. Kapranos, and D. H. Kirkwood, "Alloy development for thixoforming," in Proceedings of the 6th International Conference on Semi-Solid Processing of Alloys and Composites, pp. 443-450, Turin, Italy, 1998.

[12] B. Bieri, P. J. Uggowitzer, M. O. Speidel, T. Imwinkelried, J. Lagemann, and J. P. Gabathuler, "Influence of process parameters on the microstructure and the mechanical properties of thixoformed plates," in Proceedings of the 5th International Conference on Semi-Solid Processing of Alloys and Composites, pp. 531-537, Golden, Colo, USA, 1998.

[13] M. Stucky, M. Richard, L. Salvo, and M. Suery, "Influence of electromagnetic stirring, partial remelting and thixoforming on mechanical properties of A356 alloys," in Proceedings of the 5th International Conference on Semi-Solid Processing of Alloys and Composites, pp. 513-520, Golden, Colo, USA, 1998.

[14] Y. Birol, "Response to T6 heat treatment of extruded and thixoformed EN AW 2014 alloys," Materials Science and Engineering: A, vol. 528, no. 16-17, pp. 5636-5641, 2011.

[15] M. C. Flemings, "Behavior of metal alloys in the semisolid state," Metallurgical Transactions A, vol. 22, no. 5, pp. 957-981, 1991.

[16] W. Guo, J. Guo, J. Wang et al., "Evolution of precipitate microstructure during stress aging of an $\mathrm{Al}-\mathrm{Zn}-\mathrm{Mg}-\mathrm{Cu}$ alloy," Materials Science and Engineering: A, vol. 634, pp. 167-175, 2015.

[17] D. Liu, B. Xiong, F. Bian et al., "Quantitative study of precipitates in an $\mathrm{Al}-\mathrm{Zn}-\mathrm{Mg}-\mathrm{Cu}$ alloy aged with various typical tempers," Materials Science and Engineering A, vol. 588, pp. 1-6, 2013.

[18] I. M. Lifshitz and V. V. Slyozov, "The kinetics of precipitation from supersaturated solid solutions," Journal of Physics and Chemistry of Solids, vol. 19, no. 1-2, pp. 35-50, 1961.

[19] E. J. Zoqui, M. T. Shehata, M. Paes, V. Kao, and E. EsSadiqi, "Morphological evolution of SSM A356 during partial remelting," Materials Science and Engineering: A, vol. 325, no. 1-2, pp. 38-53, 2002. 

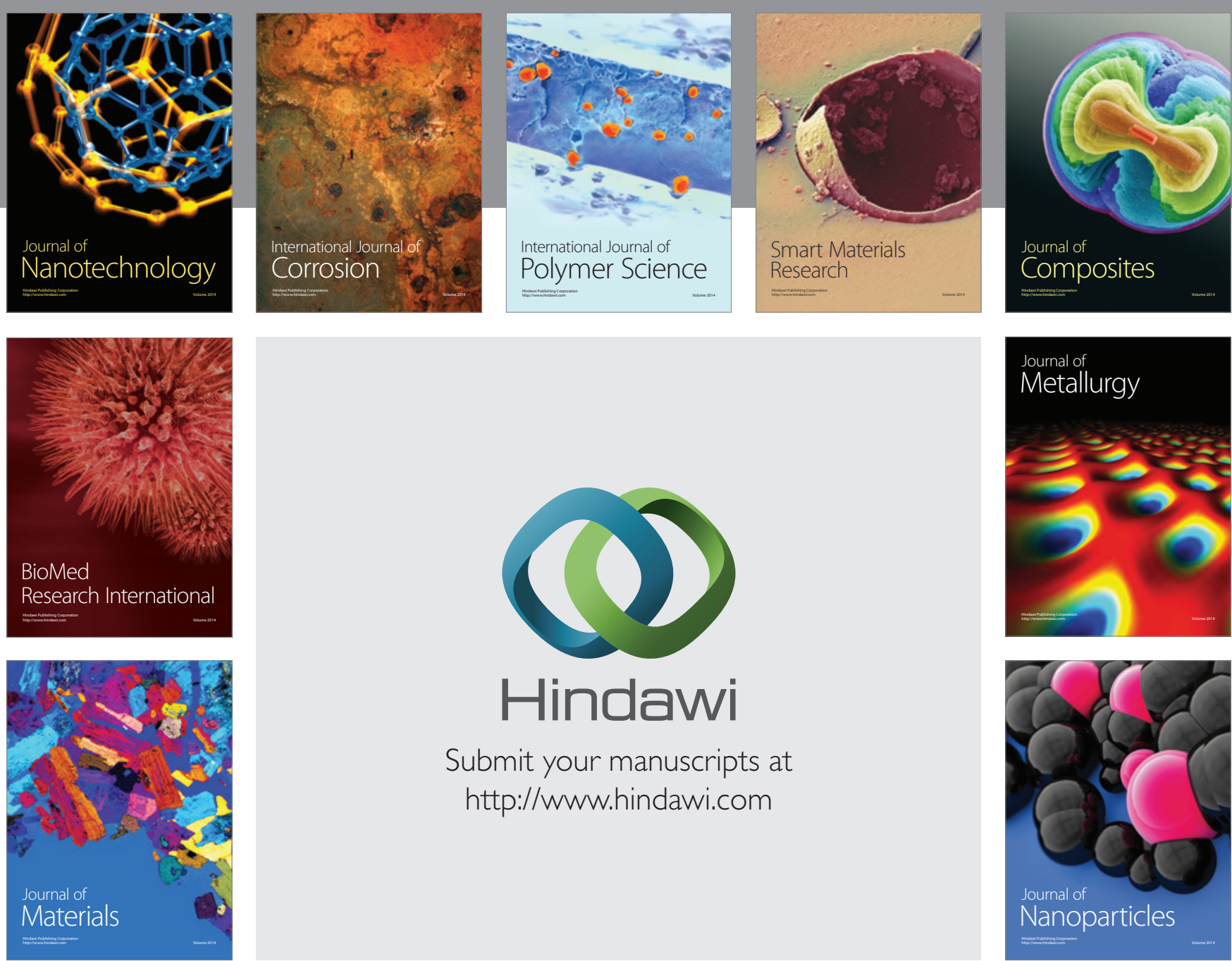

\section{Hindawi}

Submit your manuscripts at

http://www.hindawi.com

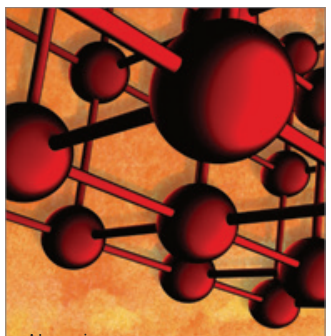

Materials Science and Engineering
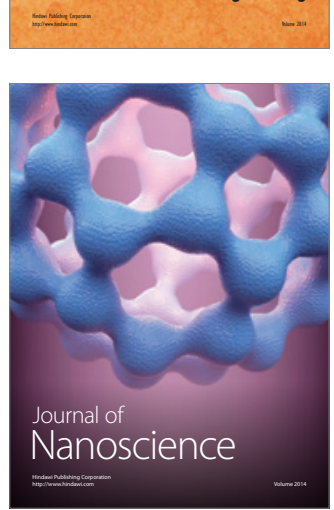
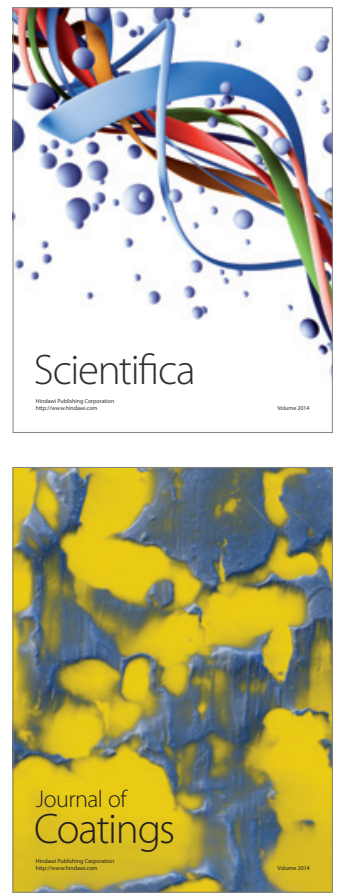
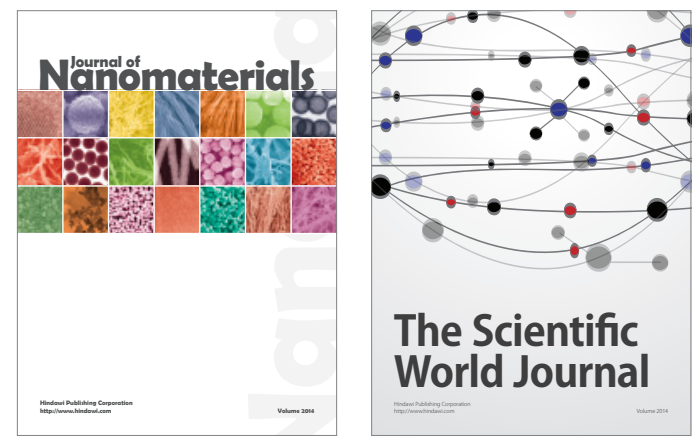

The Scientific World Journal
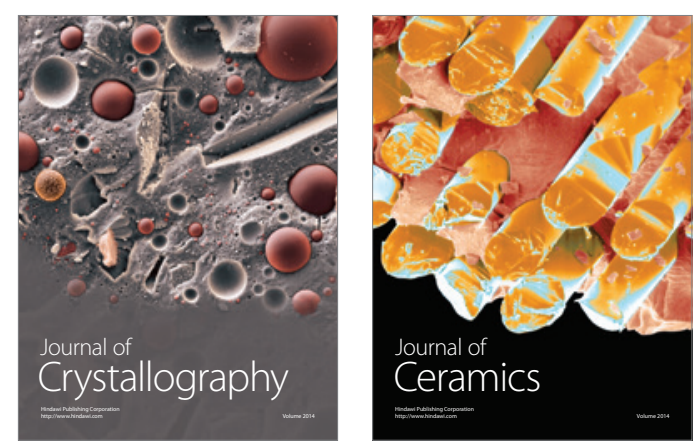
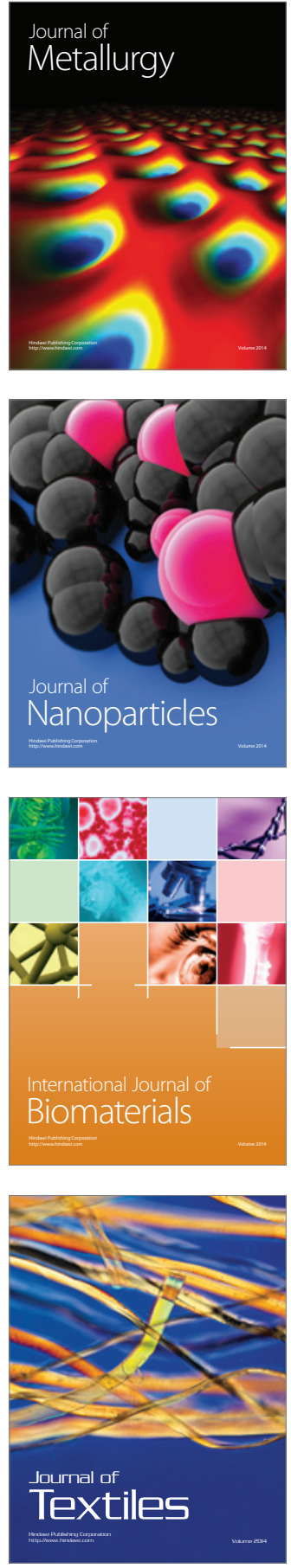